\title{
No End in Sight? US Policy on Targeted Killing by Aerial Drone Strikes: a Legal-Political Assessment
}

\author{
MATTHIAS MAASS*
}

Recently, President Obama stated: "Our systematic effort to dismantle terrorist organizations must continue. But this war, like all wars, must end." I investigate America's legal basis, its claim to self-defense in response to $9 / 11$, and conclude that this claim is weakening rapidly due to the passage of time and military successes. Similarly, the case for drone strikes as pre-emption is fading due to the damage drone strikes have done to Al Qaeda's capabilities. I conclude that overall US drone strikes follow the rules set by International Humanitarian Law (IHL). However, today America's rationale for these missions is shifting away from defeating $\mathrm{Al}$ Qaeda towards deterring its members and sympathizers. In this case, the US would most likely be in breach of IHL. I complete the analysis by claiming that the recent recognition of Obama that "this war... must end" still lacks the need for a new legal framework for America's counterterrorism efforts.

Keywords: US Foreign Policy, International Law, Drone Strikes, Targeted Killing, Terrorism 


\section{INTRODUCTION}

In mid-2013, President Barack Obama laid out US policy in regards to drones and targeted killings in a major policy speech. In it, he stated: "Our systematic effort to dismantle terrorist organizations must continue. But this war, like all wars, must end. That's what history advises. That's what our democracy demands" (Obama 2013). I will use this quotation as this investigation's motto. Below, I argue that the US policy of using armed drones for targeted killings of Al Qaeda members or affiliates is becoming obsolete. More than a decade after $9 / 11$, the claim to selfdefense is weakening. Similarly, with US successes against Al Qaeda, the case for drone strikes as pre-emption ${ }^{1}$ is fading. Finally, a possible alternative, a switch to a long-term strategy of deterrence through targeted killings, is not allowed under International Law.

While the usage of drones for targeted killing has become seemingly routine under the administrations of George W. Bush and Barack Obama, critics of this policy have been questioning the soundness of the legal framework (Bowcott 2012 ). Does International Law allow for "targeted killing" and if so, under which circumstances? In the $21^{\text {st }}$ century, the United States has become increasingly dependent on the use of aerial drones in its campaign to fight Al Qaeda and affiliated organizations. Although other states have added drones to their arsenals or are in the process of acquiring drones, the United States has been setting the agenda: it is far ahead in drone technology, has the largest arsenal, has been using drones at an unprecedented level, and has been using drones for surveillance as well as for lethal missions. In fact, it has been argued that armed drones have become the "signature weapon of the Obama administration" (Schmitt and Shanker 2011, 245). Therefore, the following analysis will be centered on the US, its policies and legal arguments. In this sense, this investigation is a single-a case study and is accordingly limited. The study will be further limited to the legal side of drone-based targeted killings. For reasons of space and analytical clarity, I will not cover other associated issues, first and foremost the questions of morality (Finkelstein, Ohlin, and Altman 2012; Guiora 2013).

Since the terrorist attacks of $9 / 11$ in 2001, US drone missions are not limited to aerial surveillance, as was the case in the past, but they now often include the objective to kill a particular individual. After 9/11, CIA drones were modified to carry arms (Melzer 2008, 40-41). Since then, the US has been relying heavily on armed drone strikes in a worldwide "War on Terror." This development has challenged International Law. Questions have been raised about the legality of drone strikes under domestic and constitutional as well as under International Law. The US has defended its policy in large part with legal justifications and made a general political and security argument of "necessity." This study investigates these dimensions of US drone strikes since 2001 under International Law and 
claims that the overriding legal argument is expiring: The US has claimed that the terrorist attack of 9/11 triggered a US military response which was justifiable as self-defense. Since then the US has been in a state of war. However, as President Barack Obama stated recently, "all wars must end" (Obama 2013). The US defense against terrorists that struck in 2001 has ended and a case for pre-emption or prevention cannot be made today. Therefore, the legal regime that has been covering drone strikes since 9/11, International Humanitarian Law, must soon be abandoned.

Drones go by different names. The 1944 Chicago Convention in article 8 refers to "pilotless aircraft" (1994); the US Federal Aviation Administration refers to unmanned aircraft, "devices used or intended to be used for flight in the air that has no onboard pilot" (Aviation Safety Unmanned Aircraft Program Office 2008; Takahashi 2012, 26); the US military generally refers to Unmanned Aerial Vehicles (UAVs) or to remotely piloted vehicles. In the interest of simplicity, I will stick with the term "drone" and exclude the usage of non-aerial "robots at war" (Singer 2009, 34-35).

Soon after the Second World War, drones appeared as tools to gather intelligence. Initially, drones were simply used for surveillance and reconnaissance (O'Connell 2010a; Singer 2009, 34). However, it was not before the wars in Balkans in the 1990s that drones became a major military asset (2009). In 2001, the US began to arm drones and use them not only for surveillance but also for direct combat (O'Connell 2010a). By the beginning of the $21^{\text {st }}$ century, drones were doing double-duty, as instruments of surveillance and as weapons. The focus here is on these armed drones that are used for targeted killing. I accept consensus definitions of "targeted killing" as "the use of lethal force" in order to kill individuals (Melzer 2008, 5).

A targeted killing is the intentional, premeditated and deliberate use of lethal force, by States or their agents acting under colour of law, or by an organized armed group in armed conflict, against a specific individual who is not in the physical custody of the perpetrator (Alston 2010, 3; also 4-5).

Today, more than 400 drones are operated out of about 60 bases by the US alone. Both the CIA and the American Air Force operate drone programs (Sanger 2012, 249). Drones are currently deployed by the US in Afghanistan, Yemen, Iraq, Pakistan, and Somalia (O'Connell 2010a). However, the US is not the only country to use drones (Gebauer 2012). A decade into the $21^{\text {st }}$ century, more than 40 states had drones in their arsenals, and by some accounts more than 50 states had them (O'Connell 2010a, 2009). Others states and actors are in the process of acquiring drones (O’Connell 2010a). The appeal of drones is simple enough. They 
are considered ideal tools for missions that fit the "three Ds," missions that are dull, dirty, or dangerous (Singer 2009, 36). Because drones are unmanned, the person piloting the vehicle is safe from harm. Moreover, what was true about aerial espionage decades ago, during the Cold War, still holds true: "...aircraft is still the most reliable, swiftest, and most elusive, as well as the most common, instrument of penetration into the foreign territorial domain..." (McDougal, Lasswell, and Vlasic 1963, 248) Finally, the operator's safety, coupled with the significant precision of its weapons, make drones an ideal tool in a fight against hierarchically organized groups of radical terrorists (Alston 2010, 3).

Since 9/11, consecutive US administrations and their legal teams have claimed that the US is in a state of war and that therefore International Humanitarian Law (IHL) governs its actions. This is the core of the US legal justifications for its wider efforts under the War on Terror generally and for its use of drones for targeted killings specifically. As a first step, I will investigate the validity of the US's claim that since 2001 it has been in a state of war. This war, the US claims, is legal under International Law as self-defense. The US has also claimed the right to anticipatory self-defense, ${ }^{2}$ and I will explore this in a second step. In either case, US actions would fall under IHL which applies during wartime. This will be the third larger step of this investigation.

If the US was found not to be in a state of war (O' Connell 2010b) and not having a reasonable case to claim self-defense and a right to pre-emption today, "targeted killings" would amount to assassinations or extrajudicial killings and would be illegal (Vogel 2010, 109). Therefore, the question if a state of war exists -and which legal framework must be applied-is of crucial importance for the US, international politics, and International Law.

\section{9/11 AND SELF-DEFENSE}

Since 2001, the US has claimed to be in a state of war against the terrorist group Al Qaeda, its supporters and associated terrorist networks, and the ensuing wars in Afghanistan and Iraq and against Al Qaeda have been fought under the rules of ius in bello ${ }^{3}$ (Vogel 2010, 106-110). Under these rules, US drone strikes are probably legal, although official secrecy regarding drone missions has been hampering a full and final legal evaluation (Sterio 2012).

The White House argues that when the US was attacked in 2001, it responded in self-defense. Drone strikes, too, were seen as part of self-defense and in 2012, President Barack Obama claimed that the American usage of armed drones for targeted killings is "part and parcel of our overall authority when it comes to battling al-Qaeda" (Sanger 2012, 252). This "overall authority" in turn relies on the argument of self-defense.

To be sure, Customary International Law and codified law authorize warfare 
in self-defense. In fact, the UN Charter in Article 51 refers to an "inherent right of individual or collective self-defense if an armed attack occurs." This provision is consistent with Customary International Law. In the International Court of Justice's 1986 decision in the case Nicaragua v United States, the judges stated that the right to self-defense is restricted to situations of "armed attack ... across an international border" that can be "classified as an armed attack" most importantly "because of its scale and effects" (1986). In short, self-defense is allowed only in case of "significant attack" (O' Connell 2010a). The attacks on the Twin Towers in New York, the Pentagon, and the failed attack on the White House meet this requirement.

America's response to the attack on its homeland was a war against the Taliban in Afghanistan, defending itself far away from where it was attacked. However, under the law, self-defense is not limited by an expansion of geographic space. There are no strict provisions that would restrain a state to limit its efforts at self-defense geographically (Vogel 2010, 108; Schmitt 2010). Self-defense is aimed at defeating an act of aggression and is not limited to denial of territorial gains. In light of this, the US is not required, under the concept of self-defense, to observe geographic limits for drone strikes.

\section{A Time Limit on Self-Defense?}

Whether the principle of self-defense is equally permissive regarding the time allowed for self-defense as it is with respect to space is less clear, however. In a statement reflecting official US government position in this matter, a former chief counterterrorism advisor to the President, John Brennan, stated that the US has been in a state of self-defense since 2001: "As a matter of international law, the United States is in an armed conflict with Al Qaeda, the Taliban, and associated forces, in response to the 9/11 attacks, and we may also use force consistent with our inherent right of national self-defense,' Brennan said" on 30 April 2012 (Zakaria 2012). In a nutshell, the US legal position is that "for as long as hostilities endure between the United States and the Taliban and al Qaeda, respectively" (Vogel 2010,114), the overarching framework of the law of war provides the US legal cover to pursue targeted killings. Hence, the argument that the US campaign of targeted killing amounts to "extrajudicial killing" has been rejected (Dixon and McCorquodale 2003, 269).

The counterargument is that too much time has lapsed since $9 / 11$ and that the attacks in 2001 cannot provide legal cover for drone missions in an ongoing armed conflict. But without the ius in bello framework, the drone strikes would have to be re-categorized as illegal assassinations, or extrajudicial killings, under transnational criminal law (Krishnan 2012). In other words, the critique of the US targeted killings by drones is that "it is essentially assassination, because the linkage to the 
attacks of September 11, 2001, ... has been strained by the passage of time" (Sanger 2012, 253). In essence, the question becomes at which point in time after 9/11 did Washington's case for on-going self-defense expire - if this argument is accepted?

To be sure, wars have lasted for decades in the past and IHL does not set strict time limits. In the past, the time of war was often bookended by declarations of war and peace treaties, but this practice has been eroding for quite some time. In the case of Al Qaeda, a formal peace treaty ending the war is unrealistic. At the same time, the exception made to the illegality of war, self-defense, is meant to protect the sovereign integrity of a state and therefore must not be used for a larger security strategy that goes far beyond responding to an attack. Put differently, the US is legally entitled to defend itself, but not to eradicate the threat of international terrorism.

One straightforward way of limiting the period of self-defense after $9 / 11$ is to link it to the defeat of the Taliban in traditional terms. After the attacks on the World Trade Center, the Pentagon, and the White House, the terrorist organization Al Qaeda claimed responsibility. The Taliban was in power in Afghanistan and refused to cooperate with the US, instead continuing to shelter Al Qaeda. However, by 2002, the Taliban was driven out of power and a new government in Afghanistan was installed and globally recognized. At this point, it has been argued, the US self-defensive campaign against Al Qaeda and the Taliban in Afghanistan came to an end. With the defeat of the state actor that had cooperated with Al Qaeda, the military and political objectives of legitimate self-defense had been achieved. From 2002, further military action by the US depended on a formal invitation by the new Afghani government for assistance. Such assistance would have to be limited to the territory of Afghanistan, the extent of territorial sovereignty of Afghanistan (O’Connell 2010a).

In contrast, the US government has advanced more expansive interpretations of the law of self-defense and its application for the ongoing campaign of targeted killings with armed drones. A full decade after 9/11, the White House argued that "[t]he United States is in an armed conflict with al-Qa'ida and its associated forces" $(2011,2)$, and that this status has remained the same since $2001(2011,3)$; this has been re-stated repeatedly:

In a series of speeches, administration officials have cited legal bases, including the congressional authorization to use military force granted after the Sept. 11 attacks, as well as the nation's right to defend itself (Miller 2012).

A senior legal advisor in the State Department under Secretary of State Hillary Clinton, Harold H. Koh, clarified the position to some extent. In 2010, he remarked that the US is in an ongoing conflict with Al Qaeda. He also hinted at 
the rationale used by the US government in support of the claim that despite years of fighting, the principle of self-defense still applies. He stated that the enemy is still "intent" on attacking the US. He argued:

As recent events have shown, al-Qaida has not abandoned its intent to attack the United States, and indeed continues to attack us. Thus, in this ongoing armed conflict, the United States has the authority under international law, and the responsibility to its citizens, to use force, including lethal force, to defend itself, including by targeting persons such as highlevel al-Qaida leaders who are planning attacks (Jacobson 2010).

In other words, Koh suggested that the conflict with Al Qaeda, justified as self-defense by the US, ceases only when the terrorist organization has abandoned its intention to carry on the fight. However, if a war of self-defense continues until the enemy abandons its intent to continue the fight, a real and final end to a conflict between a state actor and a quasi-ideology of violent religious fundamentalism is hard to foresee. Surely, the intention to carry on and the denial of defeat cannot be sufficient to legalize the continuation of a military self-defense campaign.

As CIA Director, Leon Panetta suggested a similarly expansive standpoint as Koh. On 27 June 2010 Panetta stated that self-defense after 9/11 also legitimizes efforts to prevent future attacks:

There is no question that we are abiding by international law and the law of war. Look, the United States of America on 9/11 was attacked by alQaida. They killed 3,000 innocent men and women in this country. We have a duty, we have a responsibility, to defend this country so that alQaida never conducts that kind of attack again. Does that make some of the al-Qaida and their supporters uncomfortable? Does it make them angry? Yes, it probably does. But that means that we're doing our job. We have a responsibility to defend this country and that's what we're doing. And anyone who suggests that somehow we're employing other tactics here that somehow violate international law are dead wrong. What we're doing is defending this country. That's what our operations are all about (Jacobson 2010).

Panetta avoids the pitfalls of "intent," but seems to merge legal self-defense with an ambition to eradicate a threat, arguably by (potentially legal) pre-emption or (illegal) prevention. The goal to ensure that "al-Qaida never conducts that kind of attack again" is difficult to conceptualize as self-defense, given the fact that the label of "Al Qaeda" can be transferred easily and endlessly from group to group, 
across borders and cultures. Put differently, Osama Bin Laden's Al Qaeda is not today's Al Qaeda and most likely very different from future terrorist groups that take on the name of this "franchise."

In sum, such expansive interpretations, as illustrated by the Koh's and Brennan's statements, may overreach. Modern International Law disallows war, but it makes exceptions for, among other cases, self-defense. As an exception to a general prohibition, however, it has to be restrained by immediacy and must not be used to allow a never-ending state of war. Put differently, self-defense must not become "strategic" (Katz 2012). Logically connected is the argument that today, more than a decade after the initial attack, with the actual culprits killed, and with the original enemy organization defeated, the claim to self-defense has lost validity. Although Al Qaeda still exists, it is arguably not the same enemy anymore that attacked the US in 2001. Hence, the increasing arguments that US counterterrorism efforts including the drone strikes campaign can be justified within the legal principle of pre-emption.

\section{THE WAR AGAINST TERRORISM AS PRE-EMPTION?}

In fact, more than a decade into the "War on Terror," US security policy visà-vis $\mathrm{Al}$ Qaeda has been taken on more and more the form of pre-emption. Making sure that "Al-Qaida never conducts that kind of attack again," as Brennan said, is conceptually closer to the notion pre-emption than to self-defense. Moreover, a 2011 white paper by the US Department of Justice further shifts the rationale from exclusive reliance on self-defense towards that of an "imminent threat:"

The President has authority to respond to the imminent threat posed by al-Qa'ida and its associated forces, arising from his constitutional responsibility to protect the country, the inherent right of the United States to national self-defense under international law, Congress's authorization of the use of all necessary and appropriate military force against this enemy, and the existence of an armed conflict with al-Qa'ida under international law" $(2011,1)$.

First, pre-emption does not fall within the rationale for self-defense when it counters a not-yet-materialized threat, a possible future threat, or responds to intent (O'Connell 2010a). Second, pre-emption is legal only if a rigorous set of conditions are met. Pre-emption must meet the criteria set out in the Caroline case of 1837 of a threat that is "instant, overwhelming, leaving no choice of means, and no moment of deliberation" (1934, Stevens 1989). However, it has been reported that a decade in America's "War on Terror," President Obama is now viewing the ongoing campaign of targeted killings by armed drones as a necessary effort aimed 
at forestalling another attack by $\mathrm{Al}$ Qaeda or its affiliates on the US homeland (Sanger 2012, 252). Along the same lines, his advisor and speechwriter Ben Rhodes justified drone strikes as instruments to "deal with direct threats to the United States" (Sanger 2012, 247). It appears the successor administration to President George W. Bush's has adopted the logic initially applied by Bush's VicePresident Dick Cheney that, in light of global terrorist networks and modern weapons technology, a potential threat must be countered as if it had already developed into an actual threat (Suskind 2006).

Unless a concrete threat against the US has materialized, drone strikes as preemptive self-defense do not meet the legal requirements set by International Law. Most certainly, the existence of "direct threats" cannot by itself legalize preemption under modern International Law. In fairness, the US has remained the primary target of $\mathrm{Al}$ Qaeda, its affiliates, and $\mathrm{Al}$ Qaeda-inspired terrorists. In this sense, the US remains "under attack," and it is hard to foresee an end to this situation in the near future. Still, International Law sets particularly high preconditions for pre-emption, and more than ten years after 9/11, the general threat posed by Al Qaeda is not "instant, overwhelming, leaving no choice of means, and no moment of deliberation" anymore in the general, overall sense that would a permanent counterterrorism campaign and targeted killings by armed drones.

In light of the above, the success of US counter-terrorism over the past decade has contributed massively to the fundamentally different legal situation today. The dilemma for the US is that the more successful it is in fighting Al Qaeda and in particular its leadership and key people, the less "imminent" the threat appears. In light of this, it becomes crucially important to identify the point at which Al Qaeda and its associates might still have the intention to strike at the US but are lacking the means - infrastructure, personnel, funding, logistics, etc. At this point, it would be difficult to maintain the claim that it still posed the imminent threat required under law to justify anticipatory self-defense.

On balance, the legal basis for invoking pre-emption to justify targeted killings against Al Qaeda and its affiliates worldwide is unimpressive. While there can be no argument that a considerable threat remains, it cannot be generalized to cover a long-term, strategic counterterrorism campaign. Unless a threat materiallizes that meets the Caroline standards, the overall claim that Al Qaeda remains an "imminent threat" does not seem to meet international legal standards for preemption. If, however, the US claim to self-defense was accepted, are targeted killings and drone strikes allowed under anticipatory self-defense?

\section{Targeted Killings and Pre-emption}

Missions of targeted killings by drone strikes are legal as instruments of preemption (Finkelstein 2012, Jacobson 2010). "Targeted killings are justified against 
significant and imminent threats of violent attack against a state's territory" (Zenko 2012). However, the rules of pre-emption outlined above apply. The Obama administration has taken the position that it "uses lethal force only against 'highlevel' or 'senior' members of Al Qaeda, who, in President Obama's words, 'would pose an imminent threat the United States of America"' (Zenko 2012). In other words, a rank in Al Qaeda's organization is translated into a threat-level. Assuming an "instant, overwhelming, leaving no choice of means, and no moment of deliberation" threat has materialized, the death of a particular leader might or might not be an effective tactic to pre-empt an attack. That would indeed depend on specific organizational features.

If, however, senior leaders are targeted because of their actual or assumed involvement in planning of future attacks, the imminence of the threat might be difficult to demonstrate. Put differently, how early in the preparation process of an anticipated terrorist attack on the US can a targeted killing be considered to be lawful under International Law? The difficulty of identifying the moment when a plan becomes an immediate threat is compounded by the possible access of terrorist groups to weapons of mass destruction (WMD). This in turn raises the question whether a plan to uses WMD already amounts to a threat significant enough to allow for pre-emption. In fact, this logic was suggested by VicePresident Dick Cheney, soon after the 9/11 attacks (Suskind 2006). However, it is hard to accept as legal, under current International Law, the argument that due to modern WMD, the traditional preconditions for pre-emption simply no longer apply.

Furthermore, indications are that the US has targeted individuals, possibly belonging to Al Qaeda or its affiliates, who were preparing attacks on a third state, but not on the US. In light of this, how does the traditional legal limitation on preemptive strikes relate to threats to friendly or allied third parties? For some time, the US has been operating armed drones from an airbase in Yemen.

In Yemen, some strikes apparently launched by the United States killed militants who were preparing to attack Yemeni military forces. Some of those killed were wearing suicide vests, according to Yemeni news reports. ... 'Unless they were about to get on a flight to New York to conduct an attack, they were not an imminent threat to the United States, 'said Micah Zenko, a fellow at the Council on Foreign Relations who is a critic of the strikes (Shane 2012).

It is highly problematic for the US to conduct drone strikes on targets that are not a threat to the US and, simultaneously, invoke the rights to self-defense and/or pre-emption. To be sure, a state under attack can ask for military assistance from a third party. Such assistance in a case of self-defense is legal and follows Article 51 
of the UN Charter. But without an official announcement by Yemen, the issue of invited assistance remains unsettled.

\section{Permission and "Tacit Approval" of Drone Strikes}

In addition to situations of self-defense and pre-emption, permission granted by third states for US drone strikes and targeted killing on their sovereign territory can provide the legal basis for such missions. However, such permission has not been forthcoming publically, although it might be given quietly and tacitly.

To be sure, an aerial intrusion by state aircraft into another state's national airspace is generally disallowed in International Law. The two exceptions are flights that have received permission, or intrusions legitimized by the victim state's inability or unwillingness to prevent a concrete, major threat emanating from its territory to the aggressor state. In the case of US drone missions in Pakistan, a reasonable argument has been made that these do not violate current international law, even in the absence of Pakistani formal consent, as long as the framework of self-defense applies (Paust 2009). In fact, the White House has framed its position on drone strikes along these same lines. Brennan claimed the following:

"There is nothing in international law that bans the use of remotely piloted aircraft for this purpose or that prohibits us from using lethal force against our enemies outside of an active battlefield, at least when the country involved consents or is unable or unwilling to take action against the threat," (Brennan) said (Zakaria 2012).

Despite Brennan's reference to "inability" or "unwillingness," the US claims that intrusions into foreign airspace by armed drones are conducted only with the permission of the victim state (Sanger 2012, 258-259). However, formal permission has not been forthcoming - at least it has not been made public. Given the general unpopularity of US drones strikes among the population of victim states and the perception of "surrendering" national airspace to America, the US must rely on "tacit approval" (Dixon and McCorquodale 2003, 269) for aerial intrusions and missions of targeted killings, in the Middle East as well as in Pakistan (Odun$\tan 2012,82$ ).

Such an arrangement allows for the US to claim the legality of its drone missions and provide the victim state with the cover of deniability. Given the complexities involved, the modus operandi appears acceptable to the states involved in various theaters of drone strike activities. For example, Pakistani authorities have been able to satisfy public outrage over drone strikes by protesting publically to the US (Huser 2012) while at the same time allowing Pakistani infrastructure to be used by American agents conducting drone missions (Spillius 2009). By way of 
illustration:

And, in January (2009), Prime Minister Yousuf Raza Gilani told CNN that there was no agreement between his government and the Americans to allow the strikes. The next month, though, Senator Dianne Feinstein, who is privy to the most sensitive briefings as head of the intelligence committee, inadvertently let the inconvenient truth out of the bag when she said of the drones, "As I understand it, these are flown out of a Pakistani base (Bergen and Tiedemann 2009)."

While Pakistan appears to have granted the US permission to use its airspace for drone strikes (Sanger 2012, 245), it has been resisting doing so formally and publically. The result has been an under-the-table and deniable tacit approval. It remains debatable whether such an approval amounts to permission for aerial intrusion as required under International Law. To be sure, as long as there is political agreement between the two parties involved in cases of aerial intrusion, the legal issue may not come into play.

However, the current practice of only tacitly approving US drone missions and targeted killings allows for an alternative interpretation. The US may simply disregard the legal prohibition against aerial intrusion. Frequent US drone missions over Pakistan have caused public disapproval by Pakistani authorities and a worldwide critique of the "collateral damage" of such missions. These dynamics began already under the administration of George W. Bush, when the impression emerged that the White House "deems the sovereignty of even its allies contingent" (Williams 2010, 57). This is not only undermining International Law generally, but has also proved to be counterproductive to Washington's counterterrorism efforts. Especially in Pakistan, "unauthorized" drone strikes, the loss of civilian life, and material damages, all appear to have strengthened anti-Americanism and increased support for those fighting the US in particular in the border areas between Afghanistan and Pakistan. In fact, "[t]here is ample evidence in Pakistan that the more than 300 strikes launched under Obama have helped turn the vast majority of the population vehemently against the United States" (DeYoung 2012).

\section{IS THE "WAR AGAINST TERROR” A WAR?}

Assuming the legal validity today of the US's claim to self-defense, the lawfulness of pre-emption against Al Qaeda, or the acceptability of tacit permission, drone strikes and targeted killings would fall under IHL, which governs interaction during times of war. However, does a state of war between the state USA and the organization Al Qaeda actually exist? The White House believes that the US has indeed been in a state of war with a non-state actor since 9/11 (2013). But what 
constitutes war in the legal sense and how is it conceptualized in legal terms? Traditionally, war was seen as a period of significant military conflict between two states' militaries. However, in light of major changes over time, the International Law Association (ILA) tasked a committee to investigate the contemporary understanding. In 2010, the Use of Force Committee published its report "on the meaning of conflict in International Law" (International Law Association 2010). It stated:

\section{"The Committee ... undertook extensive research into hundreds of violent situations since 1945 and identified significant state practice and opinio juris establishing that as a matter of customary international law a situa- tion of armed conflict depends on the satisfaction of two essential mini- mum criteria, namely: \\ a. the existence of organized armed groups \\ b. engaged in fighting of some intensity" (International Law Association 2010).}

The report itself does not constitute a legal document. However, the authors make the case that a modern legal concept of armed conflict has emerged as a matter of law, specifically through the evolution of Customary International Law. Following this argument, contemporary International Law considers a violent conflict a "war" and deserving the legal label "armed conflict" if organized opponents are engaged in substantial fighting.

More specifically, the 1949 Geneva conventions distinguish between wars among states (Art. 2) and "armed conflict not of an international character occurring in the territory of one" state (Art. 3) (1949). Neither category is an easy fit for the "War on Terror" the US has been fighting since 2011 against a non-traditional enemy on a global scale. The US is neither fighting another state as Article 2 requires, nor is the battlefield limited to a state's territory as Article 3 states. Al Qaeda is not a state, and drone strikes have been conducted outside the initial battlefield Afghanistan.

To be sure, the early war in Afghanistan against the Taliban could be seen as a war according to Article 2. However, that war ended in 2004 when the regime of the Taliban was replaced in Afghanistan by a new and recognized government (Vogel 2010, 111-112). In light of these limits imposed by the Geneva conventions, and in light of the modern capabilities of international terrorist networks for asymmetrical warfare, a new category has been suggested, that of "internationalized non-international armed conflicts" (Vogel 2010, 110). Despite the concept's potential usefulness, it does not constitute law today.

Assuming that the fighting of Al Qaeda will continue after international military efforts in Afghanistan have formally ceased in the near future, and given 
that most if not all "targeted killings" have been directed at Al Qaeda and its affiliates, how can these efforts be squared with the Geneva conventions? Two arguments may be advanced:

First, a contextual exploration strongly indicates that the original intention of the text's authors was for these provisions to apply to internal, non-international armed conflict (Vogel 2010, 112-113). However, in the 1940s, the current evolution in asymmetrical warfare and the emergence of fundamentalist global terrorist networks were hard to foresee. Consequently, the convention covered traditional state-to-state warfare and the only other existing category at the time, internal military-type conflict. Second, as the ILA's findings indicate, current customary international law considers the requirements of intensive fighting among organized groups as satisfying the criteria of armed conflict (International Law Association 2010). Taken together, both would allow for applying Article 3, as an analogy at least, to the current war effort of the US against Al Qaeda.

In fact, in the US Supreme Court's 2006 decision in Hamdan v. Rumsfeld (2006) used the Article 3 category, non-international armed conflict, thus providing further legal guidance in this matter (Vogel 2010, 112-113). To be sure, as of today, the legal situation is not as clear as one would wish for a matter of such importance. Still, a reasonable case can be made that the type of war that has been fought between the US and Al Qaeda can be properly categorized as a non-international armed conflict according to Article 3 of the 1949 Geneva conventions. If this is so, are US armed drone strikes legal under International Law?

\section{IHL and US Targeted Killings}

If the US is indeed in a war with Al Qaeda, IHL applies. Therefore, the question has to be asked whether targeted killing is legally permissible under the rules of ius in bello. In fact, IHL restrains military activities during the time of war. At its most fundamental level, military actions must be in accordance with the principles of military necessity, distinction between military targets and civilians, proportionality, and arguably the principle of humanity (Vogel 2010, 103). I will explore each criterion briefly now.

Are US targeted killings of members, affiliated persons, or collaborators of Al Qaeda militarily necessary? As other principles in International Law, the requirement of military necessity is broad enough to ensure overall applicability. At the same time, however, it is too general to serve as a simple checklist. Consequently, the proper way of verifying if this standard has been met is to assess each case individually, which is outside of the scope of this investigation.

However, with respect to the current war against Al Qaeda I believe one can reasonable but cautiously assume that overall US drone strikes meet this criterion. The very idea behind targeted killings suggests that this criterion is met. The 
rationale is to incapacitate a hierarchical organization by killing its top leadership. Concretely, the clear purpose of targeted killings by armed drones is to hit Al Qaeda's leadership, its high-rank individuals, and key personnel, thereby neutralizing the threat posed by Al Qaeda in a highly selective military campaign. However, no simple, general standard is available according to which the American political and military leadership could "calculate" whether the standard of military necessity has been met (Vogel 2010, 115-116; Boothby 2012). Therefore, controversies over this criterion cannot be easily solved.

However, even if the a targeted killing meets the requirement of military necessity, this person has to be actively engaged in combat before he/she can be considered legally to be a target (Bisharat 2012). The 1949 Geneva conventions provide specific provisions for sick or wounded combatants. In additions, combatants must either be in the theater of war (Bisharat 2012) or, if they are not, be "directly involved in an imminent attack;" and their apprehension must be unfeasible (Bisharat 2012). With the Iraq War formally ended and the Taliban ousted in Afghanistan, a strict reading of International Law and the theater of war-requirement raises major questions regarding US policy. In fact, what has been emerging is the notion of a "globalized battlefield," arguably with a core that over time has shifted from Afghanistan to Pakistan.

In order to keep pace with the evolution of a globally operating and "franchised" terrorist network with Al Qaeda at the center and various affiliates on the peripheries, a reconceptualization of the battlefield-requirement under IHL seems necessary. Al Qaeda has been taking advantage of the geographic features in the border area between Afghanistan and Pakistan, which has allowed it to move across the border largely at will, thus leaving and entering the battlefield (narrowly defined) as needed. As reports indicated, "the terror group was reconstituting itself in Pakistan's tribal regions" (Bergen and Tiedemann 2009).

In response, US drone missions followed their targets and crossed into Pakistani airspace or operated from airbases in Pakistan. As a result of these developments, many of the missions to kill Al Qaeda members took place inside Pakistan's territory - most notably the killing of Osama bin Laden in 2011 (although he was not killed by a drone strike) (Govern 2012).

This in turn has invited the critique that US's efforts are now taking place outside of Afghanistan and thereby outside a properly demarcated battlefield. Therefore, the legal standards necessary to categorize the hostilities as war and thus invoke the corresponding legal regime of IHL are allegedly not met (Vogel 2010, 109). In the absence of a clearly demarcated battlefield, the legal framework for US drone strikes in Pakistan would shift from ius in bello to criminal law. However, the counter-argument has been made that Pakistan, in particular its northern regions, is de facto part of the battlefield. Whether that is the case de jure, however, remains unclear at this point (Vogel 2010, 131-133). In addition, a second 
argument questions the legal necessity of a clearly bordered area in an armed conflict, in particular if the recent changes in warfare are taken into consideration:

The argument that a conflict with a non-state actor must be confined to a geographical boundary may seem appealing to some, but it is not supported by law or custom and it becomes dangerously illogical when applied to conflicts that by their nature cross borders and by definition are not between or among territorially limited states (Vogel 2010, 131).

Thus, Ryan Vogel comes to the conclusion that "location matters, but it is not overly prohibitive" (Vogel 2010, 132). More important is the reality on the ground. At least in spirit, this approach seems to be compatible with the ILA committee's findings that customary international law today emphasizes the actual existence of organized fighting over traditional criteria, such as a formal declaration of war.

In addition to the condition of military necessity and the battlefield requirement, IHL also restricts how individuals can be killed in an armed conflict (O'Connell 2010a; Bisharat 2012). A key limitation, and one that is of central importance with regard to targeted killings by armed drones, is the requirement of proportionality. The attack on a military target must be in proportion to the overall damage it will produce. In the case of drone strikes, the expected killings of civilians - the "collateral damage," must be weighed particularly carefully because of the public debate triggered by civilian casualties of drone strikes.

By its very nature, evaluating how much death and injury to people other than the targeted individual is acceptable for a drone strike to meet the legal requirement of proportionality is a difficult task. First of all, such an evaluation calls for a calculation of "acceptable" loss of human life - a morally problematic proposition at best. However, these larger ethical concerns fall outside of current IHL and are not the subject of the debate here.

The task of determining a satisfactory level of proportionality is further complicated by the fact that military gains achieved by a drone strike are often hard to measure precisely. Put differently, the question is how much impact on the war does a particular military leader have? In many ways, this can only be a hypothetical estimate. However, this issue is not unique to robotic warfare (Vogel 2010, 124-127). It applies generally in armed conflict. In the current debates, it appears that the perception of this issue is further impacted by the "unfairness" of the fight between an attacker that is safe from immediate harm and a victim who is disproportionally exposed. Moreover, the technology that allows for such remote killing is available only to an advanced and vastly more powerful state fighting a weak enemy in an underdeveloped country. Nevertheless, from a legal perspective, in an armed conflict, an armed drone is simply a new weapon and its military application is limited only by the traditional concept of proportionality. 
In fact, the precision with which armed drones can target and kill an enemy often allow for fewer deaths and destruction around the targeted individual than other traditional weapons would incur (Dershowitz 2012). Moreover, one may safely assume that advances in military technology will further enhance the precision with which an individual can be attacked in the future. Thus, the argument can be made that targeted drone strikes allow for a tighter, more limiting interpretation and application of the principle of proportionality today and in the future. In fact, one may propose that if a country has access to this technology, the requirement of proportionality may rise accordingly and unevenly vis-à-vis its enemy.

The principle of proportionality further includes the requirement to distinguish between individuals of the enemy's military and civilians. Under International Law only combatants or participating civilians can be targeted for military action. Indiscriminate killing is prohibited under IHL. Some have argued forcefully that the number of civilians killed in drone strikes is far too high to consider them proportional to the military benefits achieved by so-called targeted killing. What is more, evidence has been cited to show that drone strikes are ineffective in combatting terrorism in the first place, making their use ipse facto disproportionate (O'Connell 2010b). However, current practice of the US military and the CIA suggests that the distinction between combatants and civilians is made when drone missions are conducted (Vogel 2010, 116-122; Lewis and Crawford 2013), and that measures have been taken to avoid indiscriminate killing, legally understood, as much as possible in this particular war (Vogel 2010, 122-124).

Finally, it has been suggested that a principle of humanity must further limit the practice of targeted killings. In fact, IHL may be in the process of evolution in this area, and it has been argued that today, the existing legal principle of proportionality and the requirement to discriminate properly among targets, must be complemented by a principle of humanity (Vogel 2010, 127-129). However, as of today, it is difficult to claim that such a general requirement has already developed into International Law proper and may be best conceptualized as so-called "soft law." However, already today certain motivations for targeted killing are considered illegal.

International Law considers killing illegal if it is in revenge or if individuals are killed for actions that took place a considerable time in the past (Bisharat 2012). There is no concrete evidence that the US has been in breach of either of these two prohibitions, although it is not unthinkable that "old scores would be settled" through targeted killings or if some missions were conducted to deter Al Qaeda operatives or sympathizers. One might ask whether bin Laden was still in operational control and putting plans together for Al Qaeda attacks when he was killed in 2011, or whether he had already been neutralized as a person in actual control. If that were the case, was his assassination militarily necessary or was it motivated by revenge? This is not to suggest that bin Laden's killing was unwar- 
ranted, but rather to point out a possible dilemma created by the legal rules.

Furthermore, killing as an instrument of deterrence is considered illegal (Bisharat 2012). After 9/11, US military circles in particular became interested in deterrence as part of an evolving larger counterterrorism strategy. An early RAND report claimed that "..., the empirical record shows that even hardened terrorists dislike operational risks and may be deterred by uncertainty and risk" (Davis and Jenkins 2002, xii). Although US strategy in its "War on Terror" has been focused on defeating Al Qaeda and its affiliates (Hoag 2007), the belief that targeted killings in particular also have a deterrence effect has been carried over to the Obama administration.

The drone strikes had two complementary goals (during the Obama administration), one tactical and one strategic. The immediate, tactical goal was to bring about the death of Al Qaeda leaders, other militant commanders, and their operatives. But when looked at from a longer perspective, the fear of the remotely piloted, heavily armed drones overhead had proved to be a deterrent in itself, pushing Al Qaeda senior leaders deeper into hiding, preventing their gathering together, and keeping them constantly on alert, in motion, and off balance (Schmitt and Shanker 2011, 240-241).

Similarly, former CIA Director Michael Hayden indicated that the purpose of the ongoing campaign of drones-based targeted killings has been to disrupt and distract Al Qaeda. In late 2008, he stated the following:

Hayden went on to say that the key outcome of the drone attacks was that "we force them to spend more time and resources on self-preservation, and that distracts them, at least partially and at least for a time, from laying the groundwork for the next attack" (Bergen and Tiedemann 2009).

It is highly debatable whether "partial distraction" is a sufficient reason for targeted killings. Moreover, the strategic goal of using targeted killings to scare $\mathrm{Al}$ Qaeda commanders and deter them is problematic. The question whether such deterrence is a desirable by-product of legitimate killings, or whether targeted killings serve the primary objective of deterring other individuals from hostile action has not been answered. To be sure, distraction of the enemy and deterrence of its leaders may be effective military strategies. In the context of targeted killings and armed drones strikes they raise serious legal issues.

After all, as it is conceived in International Law, war is supposed to be the exception, not the rule. As a principle in International Law, war is supposed to have a purpose and a reason, and therefore must come to a close once the objective 
has been achieved. Already in the $19^{\text {th }}$ century, Carl v. Clausewitz stated that in times of war politics must remain the decisive factor (Clausewitz 1999, 16-17; "der politische Zweck des Krieges"; p. 221: "der Krieg is ein Instrument der Politik"). Understood along these lines, war is acceptable legally and politically only if it serves a proper purpose. From this perspective at least, justifying targeting killings of Al Qaeda members as methods of deterring participation or collaboration or as means of disrupting the organization seem highly problematic. While US policy of targeted killing is largely in line with IHL, the policy's extension into the strategic realm is, legally, immensely problematic.

\section{CONCLUSION}

The legality of using drones for targeted killings hinges critically on which label is applied to the conflict. If an armed conflict is recognized under international law, drones are just one additional type of weapon and killing legitimate enemy targets is allowed. From this perspective, the claim that the US's drone strikes amount to extrajudicial killing has been rejected as "absurd: all military deaths are extrajudicial (as is killing in self-defense and shooting a fleeing felon)" (Dershowitz 2012). If, however, targeted killings by armed drones take place outside of a proper armed conflict, then their missions are illegal under air space law and criminal law. The killings would indeed amount to assassinations or extra judicial killings. Since the 1960s, official US policy disallows assassinations (Bergen and Tiedemann 2009). An executive order by former President Gerald R. Ford prohibiting assassinations is still in force (Sanger 2012, 253).

In order to set the legal framework for US armed drone missions, the White House has been advancing two rationales: self-defense and pre-emption. With respect to the latter, the problem lies with the legal principle's rigorous preconditions. The White House has been referring to an imminent threat, but International Law sets a higher bar for pre-emptive military action. While there can be no denying the fact that the US remains under threat from religiously motivated terrorism, a generally unsafe international environment does not meet the legal minimum standards for pre-emption.

However, with regards to self-defense, America's claim is much more solid, although now arguably beginning to fade. To be sure, immediately after $9 / 11$, the US had a strong case for self-defense. Its operations against Al Qaeda and the Taliban were a military response to the attacks on the US homeland. However, the argument that since then, the US has continuously been in a state of war has been challenged because, simply put, too much time has expired. After more than a decade of a "War on Terror," US targeted killings and drone strikes appear more and more to be part of a counterterrorism strategy, and not part of self-defense in the narrow sense anymore. 
In the ongoing war, the practice of drone strikes and their military implementation seem to follow the rules imposed by IHL. However, after years of successfully using drones to target and kill members of Al Qaeda and its affiliates, the rationale for these missions seems to be shifting away from defeating Al Qaeda towards deterring its members and sympathizers. If the US policy of targeted killings were indeed to serve the purpose of strategic deterrence, major legal problems would arise and the US would most likely be in breach of IHL.

The impact on International Law of America's counterterrorism strategy that relies so heavily on armed drones and targeted killing is difficult to assess today. To be sure, "drones have not created a revolution in legal affairs" (O'Connell 2010a). However, International Law has been challenged and in some cases its principles have been stretched to the limits. Whether "major changes to the international legal system" (Peralta 2012) is still being debated, though. Even among critics of US drone policy, there is no consensus. Some argue "that stricter rules will eventually emerge to control the use (of drones) and to generally strengthen the control over national airspace through international laws in order to forestall future disputes and tensions" (Oduntan 2012, 82). Others prefer that drone missions be curtailed rigorously instead of expanding and adapting Inter-national Law. As Christof Heyns, a UN Special Rapporteur on extrajudicial, summary or arbitrary executions, stated about targeted killings: "Are we to accept major changes to the international legal system which has been in existence since World War II and survived nuclear threats?" (Peralta 2012).

What has become clear, though, is that US reliance on strikes by armed drones in its post-9/11 war against terrorist networks is not only reaching its legal boundaries but also is creating a significant backlash. The dilemma for the US is that it feels threatened but begins to realize that the current campaign must end. As Obama said: "Our systematic effort to dismantle terrorist organizations must continue. But this war, like all wars, must end" (Obama 2013). Whatever new counterterrorism strategy emerges, armed drones will most likely to be a key instrument, but on a significantly lower scale. However, whether or not this will relieve international pressure on International Law to adjust to today's drone controversy remains to be seen.

\section{REFERENCES}

1934. The Caroline Case. In Treaties and Other International Acts of the United States of America, edited by Huner Miller, 1836-1846. Washington, DC: GPO.

1944. Convention on International Civil Aviation. Chicago.

1949. Convention relative to the Protection of Civilian Persons in Time of War. Geneva. 
1986. Case Concerning the Military and Paramilitary Activities In and Against Nicaragua (Nicaragua v United States of America) (Merits). The Hague: International Court of Justice.

2006. Hamadan v. Rumsfeld, Secretary of Defense, et al. In United States Reports: US Supreme Court.

2009. The drones of war. Strategic Comments 15(4):1-2.

2011. Lawfulness of a Lethal Operation Directed Against a U.S. Citizen Who Is a Senior Operational Leader of Al-Qa'ida or An Associated Force, Department of Justice White Paper. edited by Department of Justice. Washington, DC: US Department of Justice.

2013. Washingtoner Abwägungen in der Terrorismusbekämpfung. Neue Zürcher Zeitung. Accessed 3 March. http://www.nzz.ch/aktuell/international/washing toner-abwaegungen-in-der-terrorismusbekaempfung-1.17983829.

Alston, Philip. 2010. Report of the Special Rapporteur on extrajudicial, summary or arbitrary executions. New York: United Nations, General Assembly.

Aviation Safety Unmanned Aircraft Program Office, AIR-160. 2008. Interim Operational Approval Guidance 08-01, Unmanned Aircraft Systems Operaiton in the U.S. National Airspace System. edited by Federal Aviation Administration. Washington, DC: Federal Aviation Administration.

Bergen, Peter, and Katherine Tiedemann. 2009. The Drone War. New America Foundation. Accessed 15 December. http://www.newamerica.net/publications/

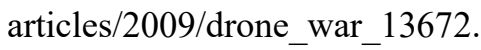

Bisharat, George. 2012. Lawful Versus Wise Policy. New York Times. Accessed 1 December 2012. http://www.nytimes.com/roomfordebate/2012/11/14/how-cantargeted-killings-be-justified/targeted-killings-may-be-lawful-but-are-they-wi se-policy.

Boothby, William H. 2012. The Law of Targeting. Oxford: Oxford UP.

Bowcott, Owen. 2012. Drone strikes threaten 50 years of international law, says UN rapporteur, US policy of using drone strikes to carry out targeted killings 'may encourage other states to flout international law.' The Guardian. Accessed 5 March. http://www.guardian.co.uk/world/2012/jun/21/drone-stri kes-international-law-un.

Brownlie, Ian. 2008. Principles of Public International Law. 7 ed. Oxford: Oxford UP.

Clausewitz, Carl v. 1999. Vom Kriege. 2 ed. Berlin: Ullstein.

Davis, Paul K. and Brian Michael Jenkins. 2002. Deterrence and Influence in Counterterrorism. A Component in the War on Al Qaeda. Santa Monica, CA: RAND National Defense Research Institute.

Dershowitz, Alan M. 2012. The Rule of Proportionality. New York Times. Accessed 1 December 2012. http://www.nytimes.com/roomfordebate/2012/11/ 
14/how-can-targeted-killings-be-justified/in-targeted-killings-the-rule-of-pro portionality-should-be-the-guiding-principle.

DeYoung, Karen. 2012. A CIA veteran transforms U.S. counterterrorism policy. New York Times. Accessed 31 October. http://www.washingtonpost.com/ world/national-security/cia-veteran-john-brennan-has-transformed-us-counte rterrorism-policy/2012/10/24/318b8eec-1c7c-11e2-ad90-ba5920e56eb3_story. html.

Dixon, Martin. 2013. Textbook on International Law. 7th ed. Oxford; New York: Oxford University Press.

Dixon, Martin, and Robert McCorquodale. 2003. Cases and materials on international law. 4th ed. Oxford: Oxford UP.

Finkelstein, Claire. 2012. Targeted Killings as Preemptive Action. In Targeted Killings, Law and Morality in an Asymmetrical World, edited by Claire Finkelstein, Fens Davd Ohlin and Andrew Altman, 156-182. Oxford: Oxford UP.

Finkelstein, Claire, Fens Davd Ohlin, and Andrew Altman, eds. 2012. Targeted Killings, Law and Morality in an Asymmetrical World. Oxford: Oxford UP.

Gebauer, Matthias. 2012. Bundeswehr und Drohnen: 'Der Finger Gottes.' Spiegel Online Accessed 9 Decembe. http://www.spiegel.de/politik/ausland/bundes wehr-und-drohnen-der-finger-gottes-a-680580.html.

Govern, Kevin H. 2012. Operation Neptune Spear: Was Killing Bin Laden a Legitimate Military Objective?, In Targeted Killings, Law and Morality in an Asymmetrical World, edited by Claire Finkelstein, Fens Davd Ohlin and Andrew Altman, 347-373. Oxford: Oxford UP.

Guiora, Amos. 2013. Legitimate Target, A criteria-Based Approach to Targeted Killing, Terrorism and Global Justice Series. Oxford: Oxford UP.

Hoag, Lyle. 2007. Give Deterrence A Chance: A Strategy Against Al Qaeda, USAWC Strategy Research Project. MA, US Army War College.

Huser, Patrick. 2012. Anhörung am Obersten Gerichtshof in Lahore. NZZ Accessed 29 December. http://www.nzz.ch/aktuell/international/pakistan-petition-drohnenangriffe-oberster-gerichtshofe-lahore-1.17856194.

International Law Association, Use of Force Committee. 2010. Final Report on the Meaning of Conflict in International Law. Internationa Law Association.

Jacobson, Louis. 2010. Do drone attacks comply with internatiional law?. PolitiFact.com-Tampa Bay Time. Accessed 4 March. http://www.politifact.com/ truth-o-meter/article/2010/jul/01/do-drone-attacks-comply-international-law/. Katz, Leo. 2012. Targeted Killing and the Strategic Use of Self-Defense. In Targeted Killings, Law and Morality in an Asymmetrical World, edited by Claire Finkelstein, Fens Davd Ohlin and Andrew Altman, 467-480. Oxford: Oxford UP. 
Krishnan, Armin. 2012. Gezielte Tötung: die Individualisierung des Krieges. 1. Aufl., Originalausg. ed. Berlin: Matthes and Seitz.

Lewis, Michael W., and Emily Crawford. 2013. Drones and Distinction: How IHL Encouraged the Rise of Drones. Georgetown Journal of International Law 44: 1127-1166.

Malanczuk, Peter. 1997. Akehurst's Modern Introduction to International Law. 7 ed. London: Routledge.

McDougal, Myres S., Harold D. Lasswell, and Ivan A. Vlasic. 1963. Law and Public Order in Space. New Haven: Yale UP.

Melzer, Nils. 2008. Targeted Killing in International Law, Oxford Monographs in International Law. Oxford: Oxford UP.

Miller, Greg. 2012. DIA sending hundreds more spies overseas. Washington Post. Accessed 5 March. http://www.washingtonpost.com/world/national-security/ dia-to-send-hundreds-more-spies-overseas/2012/12/01/97463e4e-399b-11e2b01f-5f55b193f58f story.html.

O’Connell, Mary Ellen. 2010a. The International Law of Drones. The American Society of International Law / insights 14 (36, 12 November).

O'Connell, Mary Ellen. 2010b. Unlawful Killing with Combat Drones, A Case Study of Pakistan, 2004-2009. In Legal Studies Research Paper, No. 09-43. South Bend: Notre Dame Law School.

Obama, Barack. 2013. Remarks by the President at the National Defense University. The White House, Office of the Press Secretary Accessed 18 June. http:/www.whitehouse.gov/the-press-office/2013/05/23/remarks-presidentnational-defense-university.

Oduntan, Gbenga. 2012. Sovereignty and Jurisdiction in the Airspace and Outer Space, Legal Criteria for Spatial Delimitation, Routledge Research in International Law. London: Routledge.

Paust, Jordan J. 2009. Self-defense Targetings of Non-state Actors and Permissibility of U.S. Use of Drones in Pakistan. Journal of Transnatioal Law and Policy 19(2): 237-280.

Peralta, Eyder. 2012. U.N. Investigator: U.S. Drone Program May Challenge International Law. National Public Radio. Accessed 9 December. http://www. npr.org/blogs/thetwo-way/2012/06/21/155509423/u-n-investigator-u-s-droneprogram-may-challenge-international-law.

Sanger, David E. 2012. Confront and Conceal. Obama's Secret Wars and Surprising Use of American Power. New York: Crown Publishers.

Schmitt, Eric, and Thom Shanker. 2011. Counterstrike: The Untold Story of America's Secret Campaign Against Al Qaeda. New York: Times Books.

Schmitt, Michael N. 2010. Drone Attacks Under the Jus ad Bellum and Jus in Bello: Clearing the 'Fog of Law,' In Yearbook of International Humanitarian 
Law, edited by Michael N Schmitt, Louise Arimatsu and Tim McCormack, 311-326. Berlin: Springer.

Shane, Scott. 2012. Election Spurred a Move to Codify U.S. Drone Policy. NYT Accessed 4 March. http://www.nytimes.com/2012/11/25/world/white-housepresses-for-drone-rule-book.html?hp\&_r $=0$.

Singer, Peter. W. 2009. Robots at War: The New Battlefield. The Wilson Quarterly 33(1): 30-48.

Spillius, Alex. 2009. US drones based in Pakistan, Senator Dianne Feinstein reveals in apparent gaffe. The Daily Telegraph, Accessed 20 March. http:// www.telegraph.co.uk/news/worldnews/barackobama/4616490/US-drones-ba sed-in-Pakistan-Senator-Dianne-Feinstein-reveals-in-apparent-gaffe.html.

Sterio, Melina. 2012. The United States' Use of Drones in the War on Terror: The (II)Legality of Targeted Killings Under International Law. Case Western Reserve Journal of International Law 45(1/2): 107-214.

Stevens, Kenneth R. 1989. Border Diplomacy. The Caroline and McLeod Affairs in Anglo-American-Candadisn Reltions, 1837-1842. Tuscaloosa, AL: The University of Alabama Press.

Suskind, Ron. 2006. The One Percent Doctrine : Deep Inside America's Pursuit of Its Enemies Since 9/11. New York: Simon and Schuster.

Takahashi, Timothy T. 2012. Drones in the National Airspace. Journal of Air Law and Commerce 40(4): 1-47.

Vogel, Ryan J. 2010. Drone Warfare and the Law of Armed Conflict. Denver Journal of International Law and Policy 39(1): 101 - 138.

Williams, Alison J. 2010. A crisis in aerial sovereignty? Considering the implications of recent military violations of national airspace. Area 42(1): 5159.doi: 10.1111/j.1475-4762.2009.00896.x.

Zakaria, Tabassum. 2012. White House. U.S. drone killings legal to combat threats. [internet]. Reuters Accessed 9 January. http://www.reuters.com/article/2012/ 04/30/us-obama-drones-idUSBRE83T0TN20120430.

Zenko, Micah. 2012. Transparency and Accountability. [internet]. NYT Accessed 1 December 2012. http://www.nytimes.com/roomfordebate/2012/11/14/howcan-targeted-killings-be-justified/targeted-killings-demand-transparency-andaccountability. 


\section{ENDNOTES}

1 In this manuscript, I am using "preemption" as short-hand for "anticipatory or pre-emptive action by way of self-defense," self-defense in anticipation," or "preventive" or "anticipatory self-defense." There is no consensus on the law of preemption. However, the US has been arguing that International Law knows of preemption as customary law. The argument in favor of the legality of selfdefense in the form of preemption under Customary International Law has been made especially strongly in the US since 2001 (Malanczuk 1997, 311-312, Dixon 2013, 331, Brownlie 2008, 733735).

2 Please see the comment above, following endnote 1.

3 Ius in bello "deals with the rules governing the actual conduct of hostilities, once an armed conflict has broken out" (Malanczuk 1997, 343). 